\title{
CHARACTERIZATION OF FUNGAL ISOLATES FROM PYCNIDIAAND PSEUDOTHECIA FROM LESIONS OF PHAEOSPHAERIA LEAF SPOT IN MAIZE
}

\author{
ELIANE P. CERVELATTI ${ }^{1}$, EDILSON PAIVA ${ }^{2}$, WALTER F. MEIRELLES ${ }^{2}$, CARLOS R.CASELA ${ }^{2}$, \\ FERNANDO T. FERNANDES ${ }^{2}$, FLÁVIA F. TEIXEIRA², LUZIA D. PACCOLA-MEIRELLES ${ }^{1}$.
}

${ }^{1}$ Departamento de Biologia Geral, Universidade Estadual de Londrina. Caixa Postal 6001, CEP. 86051-990 Londrina, PR.E-mail: paccola@uel.br (autor para correspondência)

${ }^{2}$ Pequisadores, Embrapa Milho e Sorgo. Caixa Postal 151, CEP. 35701-970 Sete Lagoas, MG.

Revista Brasileira de Milho e Sorgo, v.1, n.3, p.30-37, 2002

\begin{abstract}
Phaeosphaeria leaf spot, a maize disease of occurrence in Brazil, can reduce the grains production of susceptible cultivars up to $60 \%$. The causal agent of the disease was described on the basis of visual descriptions of sexual and asexual reproductive structures (pseudothecia and pycnidia) found in the lesions, and identified as being the fungus Phaeosphaeria maydis, imperfect form Phyllosticta sp. However, the isolation of this fungus is difficult and its inoculation in maize plants under controlled conditions, has not been successful in the reproduction of the symptoms. In this work, isolates obtained from pycnidia and pseudothecia present in foliar lesions were compared using isoenzymatic ( $\alpha$ and $\beta$ esterases) and RAPD patterns, in order to determine whether these two states belong to the same etiological agent. These techniques clearly distinguished between isolates from pycnidia and pseudothecia, indicating that these structures belong to distinct fungal species, and not to the anamorphic and teleomorphic states of the same agent, as previously suggested. Based on morphological characteristics, the isolate from pycnidia was classified as Phoma tropica, an opportunistic fungus that colonizes pre-established lesions, and not as a Phyllosticta sp. as described initially.
\end{abstract}

Key-words: Zea mays, Phaeosphaeria maydis, Phyllosticta, isozymes, RAPD analysis

\section{CARACTERIZAÇÃO DE ISOLADOS FÚNGICOS DE PICNÍDIOS E PSEUDOTÉCIOS DE LESÕES DA MANCHA FOLIAR DE PHAEOSPHAERIA EM MILHO}

\begin{abstract}
RESUMO - A doença foliar descrita no Brasil como sendo mancha por phaeosphaeria em milho pode reduzir a produção de grãos em até $60 \%$, quando se utilizam cultivares suscetíveis. $\mathrm{O}$ agente causal da doença foi descrito a partir de observações visuais de estruturas reprodutivas sexuadas e assexuadas (pseudotécios e picnídios) encontradas no interior das lesões, e identificado como sendo o fungo Phaeosphaeria maydis, forma imperfeita Phyllosticta sp. No entanto, esse fungo é de difícil isolamento e sua inoculação em plantas de milho, sob condições controladas, não tem apresentado sucesso na reprodução dos sintomas. Isolados obtidos a partir de picnídios e pseudotécios presentes nas lesões foram comparados através do padrão isoenzimático ( $\alpha$ e $\beta$ esterases) e RAPD, visando determinar se esses dois estados são realmente pertencentes ao mesmo agente etiológico. Os resultados obtidos permitiram a separação dos isolados oriundos de picnídios daqueles oriundos de pseudotécios em grupos bem distintos, indicando que essas estruturas pertencem a espécies fúngicas distintas, e não ao estado anamórfico e teleomórfico do mesmo agente, como vem sendo atribuído. A partir da
\end{abstract}


classificação baseada em caracteres morfológicos, o fungo isolado de picnídios foi identificado como Phoma tropica, um fungo oportunista colonizador de lesões preestabelecidas, e não Phyllosticta sp como descrito inicialmente.

Palavras-chave: Zea mays, Phaeosphaeria maydis, Phyllosticta, isoenzimas, RAPD

The foliar disease of maize commonly known as phaeosphaeria leaf spot was first described in India by Rane et al. (1965) and, by the mid-1980s, was reported in Brazil (Fantim, 1994). Balmer \& Pereira (1987) and Casela (1998) noted that, in recent years, there has been an increase in the significance of this disease in Brazil, where plants are generally affected at the end of the crop growing season, although younger plants may also be affected causing premature dryness in more severe attacks. The symptoms begin with the appearance of slightly chlorotic, water-soaked lesions on the leaves, which later become necrotic and straw-colored. The incidence of infection increases in conditions of high relative humidity and moderate temperatures (Fantim, 1994), and may reduce grain yield up to $60 \%$ (Fernandes \& Oliveira, 1997).

Initially, Phyllosticta sp was described as the etiological agent of phaeosphaeria leaf spot, based on observations of pycnidia inserted on plant tissue in the center of the lesions. Depending on climatic conditions and season, sexual reproductive structures, described as perithecium, may also be seen (Rane et al., 1965). More recent reports have identified these sexual structures as pseudothecium (Fantim, 1994). Fungi producing these pseudothecia have been identified as Phaeosphaeria maydis, the perfect form of Phyllosticta sp, an ascomycete of the family Pleosporaceae. The anamorphic and teleomorphic states of the causal agent were described on the basis of visual descriptions of the reproductive structures (pycnidium and pseudothecium) present in the lesions.

In this work we have used biochemical and molecular techniques to compare the isolates from pycnidia with those from pseudothecia, in order to establish whether these two structures are really different states of the same agent.

\section{Material and Methods}

\section{Fungal isolates}

Fungal isolates used in this study are described in Table 1. All cultures were prepared from monoconidial isolates. Isolate 6 , obtained from pycnidia was provided by the Plant Pathology Laboratory of EMBRAPA Maize and Sorghum in Sete Lagoas, Minas Gerais, Brazil, and isolate 89, obtained from pseudothecium, was kindly provided by Dra G. Fantim of the Biological Institute of Campinas, São Paulo, Brazil. All other isolates were obtained from foliar lesions containing reproductive structures. The isolates were cultivated in oat media ( $60 \mathrm{~g}$ of oat flakes $+15 \mathrm{~g}$ of agar $+1000 \mathrm{~mL}$ of distilled water $)$ for 20 days at $22 \pm 2{ }^{\circ} \mathrm{C}(12 \mathrm{~h} \mathrm{light} /$ $12 \mathrm{~h}$ dark).

Polyacrylamide gel electrophoresis (PaccolaMeirelles et al., 1988)

The esterase isoenzyme patterns of 30 isolates ( 15 from pycnidia and 15 from pseudothecia) were evaluated. The isolates were cultivated in potato dextrose broth, $\mathrm{pH} 6.9$, at $22 \pm 2{ }^{\circ} \mathrm{C}(12 \mathrm{~h}$ light $/ 12 \mathrm{~h}$ dark) for seven days. The resulting mycelia were washed three times in distilled water, filtered, macerated in liquid $\mathrm{N}_{2}$ and homogenized in $0.5 \mathrm{M}$ Tris-HCl, pH 6.8 (1 g of mycelia: $1 \mathrm{~mL}$ of buffer). After centrifugation at $40.000 \mathrm{xg}$ for $20 \mathrm{~min}$, the samples were separated by electrophoresis (Paccola-Meirelles et al., 1988) on 10\% polyacrylamide gel. The pattern of $\alpha$ and $\beta$ esterases 
was determined using the substrate $1 \% \alpha$ - naphthyl acetate and $1 \% \beta$ - naphthyl acetate.

\section{DNA extraction}

For total DNA extraction, according to Maki et al. (2001), $400 \mathrm{mg}$ of mycelia of each isolate were macerated in liquid $\mathrm{N}_{2}$, and extracted in $4 \mathrm{~mL}$ of extraction buffer (200 mM Tris-HCl, $\mathrm{pH} 8.0+250$ $\mathrm{mM} \mathrm{NaCl}+25 \mathrm{mM}$ EDTA, $\mathrm{pH} 8.0+1 \% \mathrm{SDS}+$ $1 \mu 1 \beta$ - mercaptoethanol per $\mathrm{mL}$ of buffer) and incubated at $65^{\circ} \mathrm{C}$ for $15 \mathrm{~min}$. Two milliliters of phenol were then added to the samples and centrifuged for 15 min at $10.000 \mathrm{xg}$. The supernatant was collected and transferred to centrifuge tubes, followed by addition of phenol and chloroform ( $1 \mathrm{~mL}$ each) to the tubes. After centrifugation for $15 \mathrm{~min}$ at $10.000 \mathrm{xg}$, $2 \mathrm{~mL}$ of chloroform-octanol $(24: 1 \mathrm{v} / \mathrm{v})$ was added to the supernatant and again centrifuged for $15 \mathrm{~min}$. Icecold isopropanol $(8 \mathrm{~mL})$ was added to the supernatants. After precipitation, the DNA was transferred to microtubes containing $100 \mu 1$ of TE (0.5 mL of $1 \mathrm{M}$ Tris $+0.1 \mathrm{~mL}$ of $0.5 \mathrm{M}$ EDTA, $\mathrm{pH}$ 8.0). The DNA concentration was estimated by comparison with DNA standards on $0.8 \%$ agarose gel electrophoresis.

\section{Primers and RAPD (Random Amplified Polymorphic DNA) analysis}

Nineteen previously selected primers were used in the analysis: OPA3 (5' AGT CAG CCA C 3'), OPA4 (5' AAT CGG GCT G 3'), OPA8 (5' GTG ACG TAG G 3'), OPA9 (5' GGG TAA CGC C 3'), OPA10 (5' GTG ATC GCA G 3'), OPA13 (5' CAG CAC CCA C 3'), OPA14 (5' TCT GTG CTG G 3'), OPW3 (5' GTC CGG AGT G 3') OPW4 (5' CAG AAG CGG A 3'), OPW5 (5' GGC GGA TAA G 3'), OPW6 (5' AGG CCC GAT G 3'), OPW8 (5' GAC TGC CTC T 3'), OPW9 (5' GTG ACC GAG T 3'), OPW10 (5' TCG CAT CCC T 3'), OPW11 (5' CTG ATG CGT G 3'),
OPW12 (5' TGG GCA GAA G 3'), OPW13 (5' CAC AGC GAC A 3'), OPW16 (5' CAG CCT ACC A 3'), OPW20 (5' TGT GGC AGC A 3'). Each amplification reaction contained $9.5 \mu$ lof sterile, ultra-pure water, $2.5 \mu 1$ of PCR buffer $10 \mathrm{X}(50 \mathrm{mM}$ $\mathrm{KCl}+100 \mathrm{mM}$ Tris-HCl, $\mathrm{pH} 8.6+0.1 \%$ Gelatin + $2 \mathrm{mMMgCl}_{2}$ ), $1 \mu$ l of dNTP solution (containing 100 $\mu \mathrm{M}$ each of dATP, dTP, dGTP and dTTP), $1 \mu 1$ of primer $(4 \mu \mathrm{M}), 1 \mu$ l ofDNA-Taq polymerase $1 \mathrm{U} / \mathrm{mL}$ and $10 \mu \mathrm{L}$ of DNA solution $(5 \mathrm{ng} / \mu \mathrm{l})$. Polymerase chain reaction (PCR) was done using a 100 PTC (programmable thermal controller) thermocycler (Perkin Elmer - Gene Amp ). The program used consisted of $1 \mathrm{~min}$ at $95^{\circ} \mathrm{C}$ for initial denaturation followed by 35 cycles of amplification ( 10 seconds at $94^{\circ} \mathrm{C}$ for denaturation, $1 \mathrm{~min}$ at $36^{\circ} \mathrm{C}$ for annealing and $2 \mathrm{~min}$ at $72^{\circ} \mathrm{C}$ for extension by Taq-polymerase and incorporation of the nucleotides) and a final extension for $7 \mathrm{~min}$ at $72^{\circ} \mathrm{C}$ after which the tubes were maintained at $4^{\circ} \mathrm{C}$ (Maki et al. 2001). The amplification products were separated on $1 \%$ agarose gels, stained with ethidium bromide and photographed under UV light with Polaroid film. The data obtained by RAPD were analyzed by the presence (1) and absence ( 0 ) of a specific band on the gel for each one of the 19 primers tested. These analyses were carried out considering a total number of 163 polymorphic bands and the program used was Statistica 5.0 version (StatSoft, Inc.)

\section{Pathogenicity tests}

Pathogenicity tests were performed on 30day-old plants, of the susceptible maize cultivar HS200. Conidia and ascospores of isolates 6 and 89 , were produced in oat culture medium at $22^{\circ} \mathrm{C}$, and a $10^{6} \mathrm{~mL}^{-1}$ spore suspension was sprayed onto the leaves. Control plants were sprayed with sterilized water. Three pots with two plants per pot were used in each treatment. After inoculation plants were kept for $60 \mathrm{~h}$ in a dew chamber with $100 \%$ relative humidity. 


\section{Results and Discussion}

The frequency of pycnidia and pseudothecia in phaeosphaeria leaf spot lesions of 30 maize hybrids were evaluated. Pycnidia were seen in only $8.8 \%$ of the lesions and pseudothecia in $7.3 \%$; about $79.3 \%$ of the lesions showed no reproductive structures and $2 \%$ had both structures. The isolation frequency of the fungus described as the patogenic agent was low, about $4,4 \%$. Several fungal species other than the ones described as being the causal agent of phaeosphaeria leaf spot were also isolated. Isolates obtained from picnidia and pseudothecia are listed in Table1.

TABLE 1. Isolates obtained from lesions containing reproductive structures and their respective origins.

\begin{tabular}{cl}
\hline Isolates* & \multicolumn{1}{c}{ Locality } \\
\hline 1 & Chapadão do Céu (GO) \\
5 & Goianćsia (GO) \\
6 & Sete Lagoas (MG) \\
9 & Sete Lagoas (MG) \\
12 & Sete Lagoas (MG) \\
16 & Sete Lagoas (MG) \\
17 & Sete Lagoas (MG) \\
22 & Sete Lagoas (MG) \\
23 & Sete Lagoas (MG) \\
25 & Sete Lagoas (MG) \\
26 & Uberlândia (MG) \\
27 & Uberlândia (MG) \\
28 & Uberlândia (MG) \\
29 & Uberlândia (MG) \\
30 & Passo Fundo (MG) \\
41 & Araçatuba (SP) \\
42 & Batatais (SP) \\
43 & Jardinópolis (SP) \\
44 & Guaira (SP) \\
46 & Rolândia (PR) \\
47 & Londrina (PR) \\
51 & Warta (PR) \\
52 & Sete Lagoas (MG) \\
& \\
\hline 1 &
\end{tabular}

\section{Continuação da Tabela 1.}

$\begin{array}{lll}53 & \text { Sete Lagoas (MG) } \\ 57 & \text { Sete Lagoas (MG) } \\ 58 & \text { Sete Lagoas (MG) } \\ 59 & \text { Sete Lagoas (MG) } \\ 61 & \text { Sete Lagoas (MG) } \\ 62 & \text { Sete Lagoas (MG) } \\ 64 & \text { Sete Lagoas (MG) } \\ 65 & \text { Sete Lagoas (MG) } \\ 66 & \text { Sete Lagoas (MG) } \\ 67 & \text { Sete Lagoas (MG) } \\ 68 & \text { Sete Lagoas (MG) } \\ 69 & \text { Sete Lagoas (MG) } \\ 71 & \text { Sete Lagoas (MG) } \\ 74 & \text { Sete Lagoas (MG) } \\ 75 & \text { Sete Lagoas (MG) } \\ 79 & \text { Sete Lagoas (MG) } \\ 80 & \text { Sete Lagoas (MG) } \\ 84 & \text { Sete Lagoas (MG) } \\ 86 & \text { Sete Lagoas (MG) } \\ 89 & \text { Anhembi (SP) } \\ 90 & \text { Ponta Grossa (PR) } \\ 93 & \text { Cascavel (PR) }\end{array}$

*1-51: isolates from pycnidia; 52-93: isolates from pseudothecia.

The electrophoretic profiles of $\alpha$ and $\beta$ esterases allowed the separation of isolates obtained from pseudothecia and pycnidia, suggesting that these isolates belong to different species. Esterases profiles of isolates obtained from pseudothecia were very similar, with only one polymorphic band seen in isolate 68 (Figure 1). The electrophoretic pattern of this isolate indicates that it belongs to a different species. By contrast, there was an extensive variation among the esterase patterns of isolates obtained from pycnidia (Figure 2).

In the RAPD analysis, of the 19 primers evaluated, 11 (OPA3, OPA4, OPA8, OPA9, OPA10, OPA13, OPW4, OPW5, OPW6, OPW12 


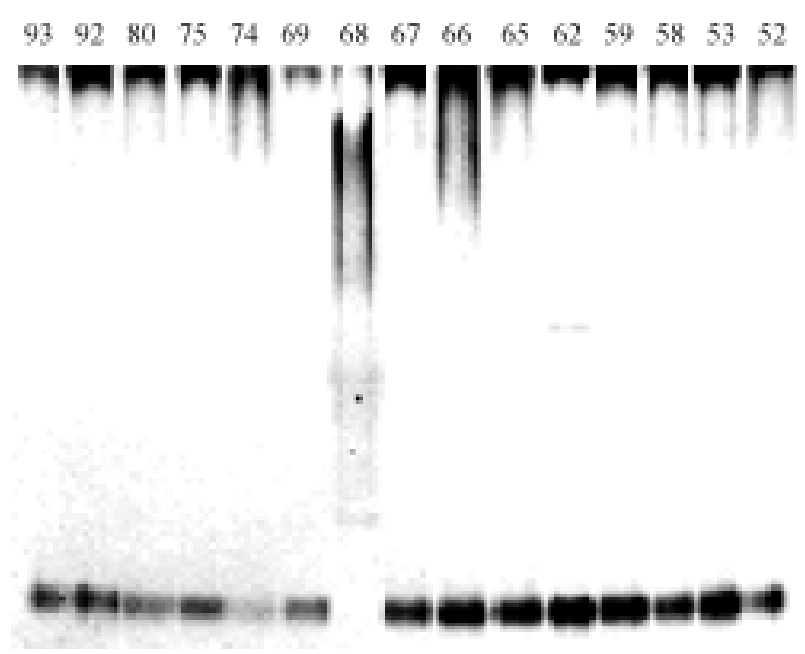

FIGURE 1. Electrophoretic patterns of $\alpha$ and $\beta$ esterases of 15 isolates obtained from pseudothecia present in phaeosphaeria leaf spot lesions of maize.

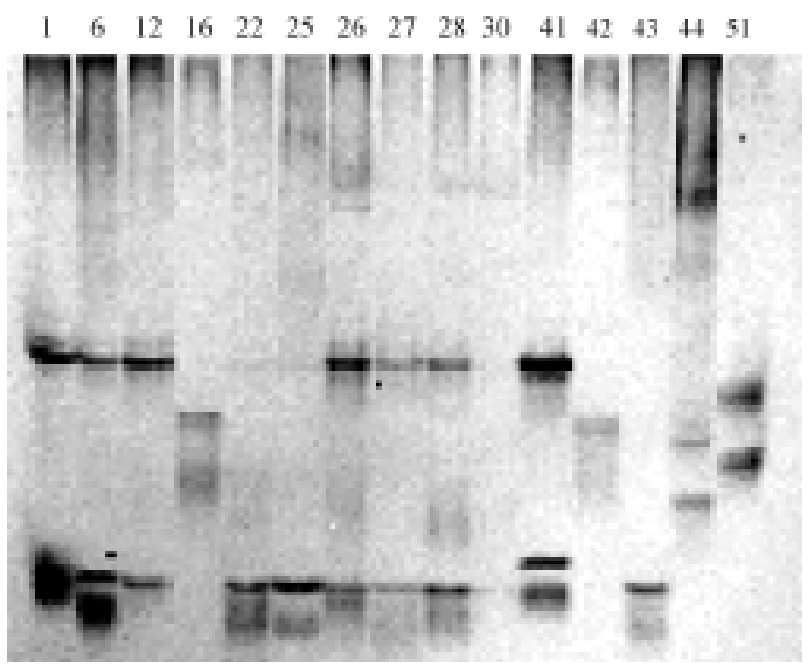

FIGURE 2. Electrophoretic patterns of $\alpha$ and $\beta$ esterases of 15 isolates obtained from pycnidia present in phaeosphaeria leaf spot lesions of maize.

and OPW16) produced clear, reproducible DNA bands for isolates from both pycnidia and pseudothecia. The RAPD patterns of primers showed clear differences between the two groups (Figures 3 A,B and 4 A,B), and a total of 163 polymorphic bands were observed. Clusters analysis (Figure 5) separated the isolates into three groups: the first, contained the isolates of Phyllosticta $\mathrm{sp}$ (with the exception of isolate 68); the second contained isolates of Phaeosphaeria maydis and, the third included only isolate 90 . The RAPD analysis confirmed the results obtained by the isoenzymatic analysis allowing the separation of the isolates of Phyllosticta sp and Phaeosphaeria maydis into distinct groups. These results suggested that pycnidia and pseudothecia present in phaeosphaeria leaf spot lesions belong to two different species rather than being the anamorphic and teleomorphic states of the same fungus.

The genetic variation among isolates from the same geographic origin such as isolates 6,9,16, 17 and 23 collected in Sete Lagoas, (MG) was sometimes greater than that among isolates from different regions. This observation may reflect the action of mutations and, possibly, genetic exchange between strains, since anastomosis of hyphae has been reported in this species (Cervelatti et al., 1998). Similar observations were made by Machado et al. (1997), in isolates of Cercospora sojina collected in Minas Gerais.

Isolate 6 (from pycnidia) and isolate 89 (frompseudothecia) were classified according to their morphological characteristics. Isolate 6 originally described as Phyllosticta sp was classified as Phoma tropica and isolate 89 described as Phaeosphaeria maydis was classified as belonging to the Phaeosphaeria genus.

The species Phoma tropica has been described in association with leaf spots and stem lesions in more than 20 species of ornamental plants in green houses in Holland and Germany (Schneider \& Boerema, 1975).

Errors in the classification of Phoma and Phyllosticta species are relatively common. As an example, Phoma glomerata classified by Simay (1994) was originally deposited in culture banks as Phyllosticta maculiformis, Phyllosticta sojoecola and Phoma pomorum. Many fungi are erroneously 


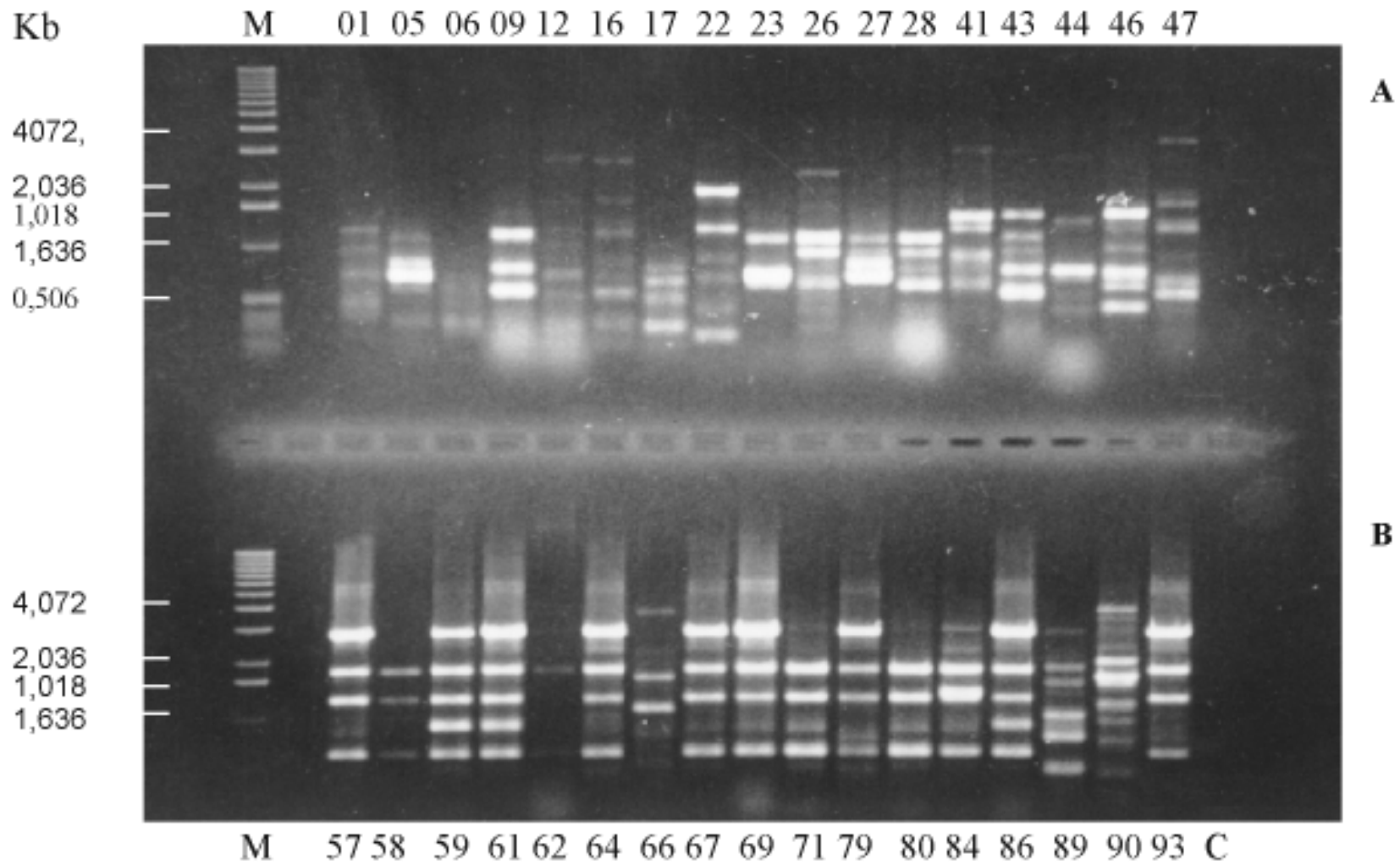

FIGURE 3. Amplification products generated from 17 isolates obtained from pycnidia (A) and 17 isolates obtained from pseudothecia (B) from phaeosphaeria leaf spot in maize, using primer OPA8. C: negative control (sample containing only PCR buffer, primer dNTPs, Taq polymerase and ultra pure water). M: Molecular weight markers; 100 pb DNA Ladder(GIBCO BRL). Fragment sizes in Kilobases are indicated on the left.

classified as Phyllosticta because of this species ability to establish itself in lesions caused by other agents and, in many cases, the classification of Phoma and Phyllosticta is based on the type of host, and not on characteristics observed during fungus cultivation.

In the pathogenicity tests, conidia and ascospores from isolates 6 and 89 , did not reproduce symptoms of phaeosphaeria leaf spot under controlled conditions, and Paccola-Meirelles et al. (2001) has suggested that these fungi are not the primary agents of the infection. Although phaeosphaeria leaf spot has been described as a fungal disease, these authors suggest the possibility of an association with bacteria, the Pantoea ananas. According to their hypothesis, the bacteria initiates infection, and the lesion, later on, is invaded by a co-inhabiting fungus. This explains the high incidence of lesions without fungal structures and the low frequency of Phaeosphaeria sp. isolated from reproductive structures.

Our results indicate that the pycnidia observed in the center of the lesions of the disease described as phaeosphaeria leaf spot in maize do not belong to the fungus Phyllosticta sp as it has been attributed, but rather belong to the saprophytic species, Phoma tropica, that develops in lesions produced by other pathogenic agents. 


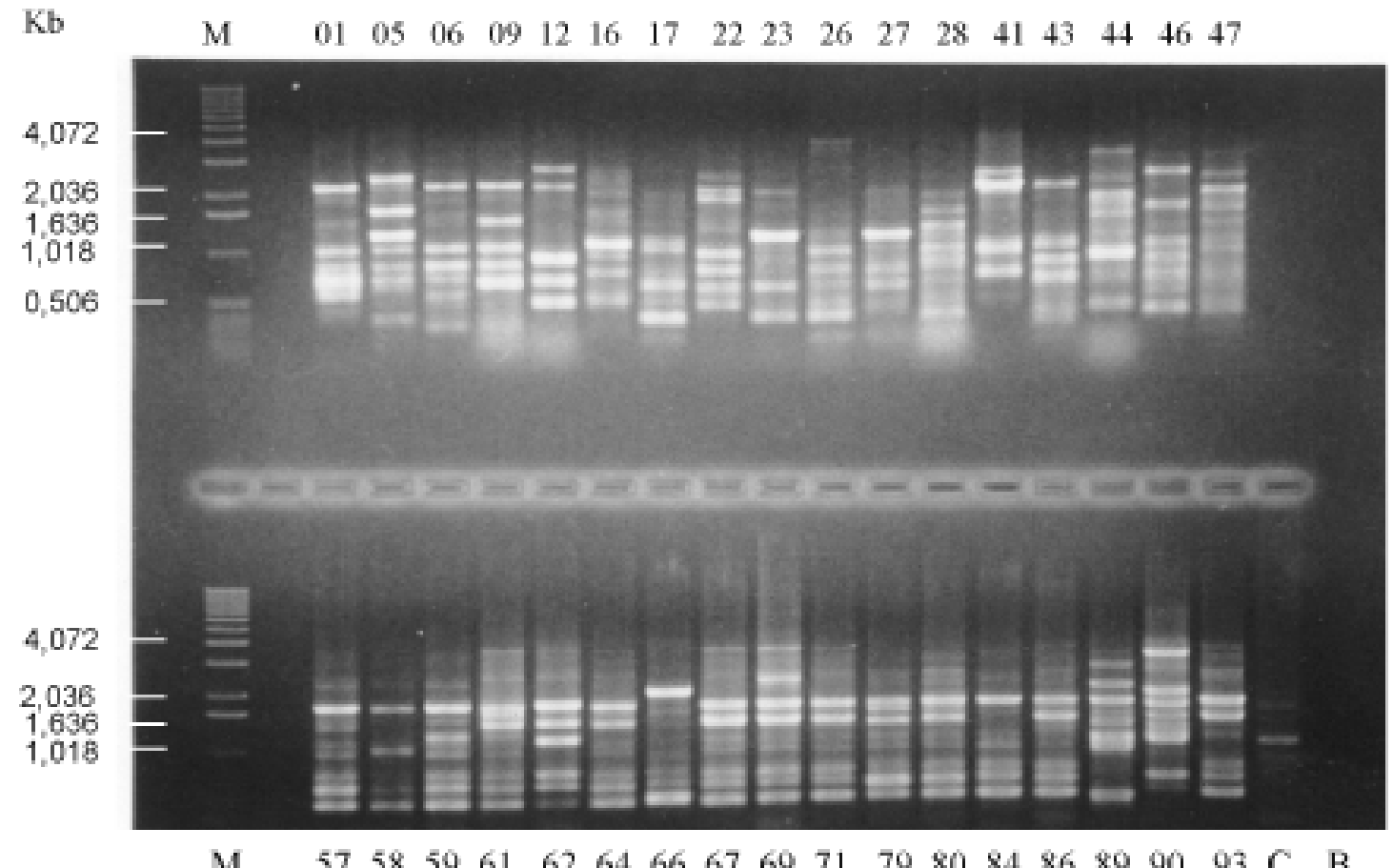

FIGURE 4. Amplification products generated from 17 isolates obtained from pycnidia (A) and 17 isolates obtained from pseudothecia (B) from phaeosphaeria leaf spot lesions in maize, using primer OPA13. C: negative control (sample containing only PCR buffer, primer dNTPs, Taq polymerase and ultra pure water). M: Molecular weight markers; 100 pb DNA Ladder (GIBCO BRL). Fragment sizes in Kilobases are indicated on the left.

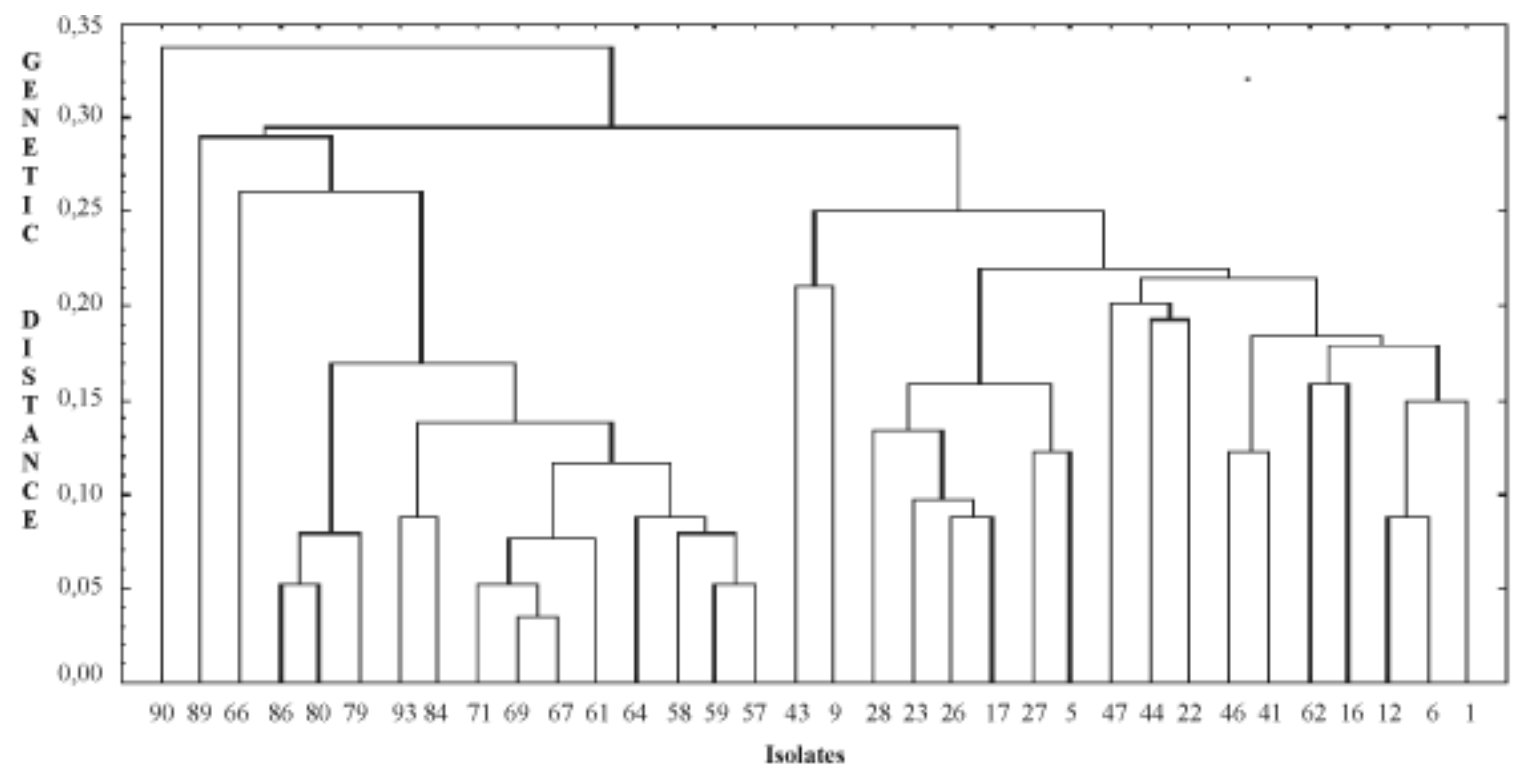

FIGURE 5. Dendrogram of the relationships among 34 isolates obtained from pycnidia and pseudothecia present in the lesions of phaeosphaeria leaf spot in maize, based on random amplified polymorphic DNA (RAPD) analysis. 


\section{Conclusion}

The pycnidia and pseudothecia present in the lesions of phaeosphaeria leaf spot belong to distinct fungal species (Phoma tropica and Phaeosphaeria sp., respectively) and not to the anamorphic and teleomorphic states of the same agent.

\section{Acknowledgements}

The authors thank CNPq (Conselho Nacional de Pesquisa e Desenvolvimento Científico) for the financial support. The authors are grateful to Dra Elza A. Luna of the Mycology Department, Universidade Federal de Pernambuco, Recife, PE/ Brazil, for the fungus identification.

\section{References}

BALMER, E.; PEREIRA, O.A.P. Doenças de milho. In: PATERNIANI, E.; VIÉGAS, G.P. (Ed.). Melhoramento e produção do milho. Campinas: Fundação Cargill, 1987. v.2, cap.14, p. 595-634.

CASELA, C.R. The Phaeosphaeria leaf spot. In: CASELA, C.R.; RENFRO, R.; KRATTIGER, A. (Ed). Diagnosing maize diseases in Latin American. Ithaca: ISAAA/ Brasília: EMBRAPA, 1998, p. 15-17.

CERVELATTI, E.P., PACCOLA-MEIRELLES, L.D.; FERNANDES, F.T. Caracterização citológica de Phyllosticta sp. (f.p. Phaeosphaeria maydis). In: CONGRESSO NACIONAL DE MILHO E SORGO, 22. 1998, Recife. Globalização e segurança alimentar: Anais... Recife: IPA, 1998. CD. ROM.

FANTIM, G.M. Mancha por Phaeosphaeria, doença de milho vem aumentando sua importância. Biológico, Campinas, v.56, p. 39, 1994.

FERNANDES, F.T.; OLIVEIRA, E. de. Principais doenças na cultura do milho. Sete Lagoas:
EMBRAPA-CNPMS, 1997. 80p. (EMBRAPACNPMS. Circular Técnica, 26).

MACHADO, M.A.; BARROS, E.G.; VASCONCELOS, M.J.V.; GOMES, J.L.L.; MOREIRA, M.A. RAPD analysis for characterization of Cercospora sojina isolates. Fitopatologia Brasileira, Brasilia, v.22, p. 366-369, 1997.

MAKI, C.S.; TEIXEIRA, F.F.; PAIVA, E.; PACCOLA-MEIRELLES, L.D. Analyses of genetic variability in Lentinula edodes through mycelia responses to different abiotic conditions and RAPD molecular markers. Brazilian Journal of Microbiology, São Paulo, v.32, p. 170 - 175, 2001.

PACCOLA-MEIRELLES, L.D; FERREIRA, A.S; MEIRELLES, W.F.; MARRIEL, I.E.; CASELA, C.R. Detection of a bacterium associated wiyh a leaf spot disease of maize in Brazil. Journal of Phytopathology, Berlin, v. 149, p. 275-279, 2001.

PACCOLA-MEIRELLES, L.D.; VALARINI, M.J.; AZEVEDO, J.L.; ALFENAS, A.C. Manual de técnicas eletroforéticas em microrganismos. Piracicaba: FEALQ,. 1988. 54p.

RANE, M.S; PAYAK, M.M.; RENFRO, B.L. A Phaeosphaeria leaf spot of maize. Indian Phytopathological Society Bulletin, New Delhi, v.3, p. 8-10, 1966.

SCHNEIDER, R.; BOEREMA, G.H. Phoma tropica $n$. sp., ein an Gewachshauspflanzen haufig vorkommender, nicht pathogener Pilz. Journal of Phytopathology, Berlin, v.83, p. 360-366, 1975.

SIMAY, E.I. Comparative study of Phoma glomerata (Corda) Wollenber et al., Hochapfel isolates. Acta Phytopathologica et Entomologica Hungarica. Budapest, v. 29, p. 67-72, 1994. 